\title{
Influence of Green Transformational Leadership and Innovation Towards Corporate Sustainability Through Green Motivation at PT. Tri Digital Perkasa
}

\author{
Irma Kurniasih $^{1}$, Lenny Christina Nawangsari ${ }^{2}$ \\ \{rma kurniasih@student.upi.edu ${ }^{1}$, lenny.christina@mercubuana.ac.id $\left.{ }^{2}\right\}$ \\ Mercu Buana University, Jakarta, Indonesia ${ }^{12}$
}

\begin{abstract}
Start-up companies make many contributions in absorbing the workforce, where $88.25 \%$ have a number of employees above 50 people, to maintain corporate sustainability we need to identify several factors. The most important factor is human resources in leadership, especially green transformational leadership. Through the correlative quantitative research method, this study calculates and describes the effect of Green Transformational Leadership, Innovation and Green Motivation on Corporate Sustainability. The data collection method in this study used a questionnaire method by taking 64 respondents in PT. Mighty Tri Digital. Data were collected through the literacy study and questionnaires, with the test instrument construct validity and reliability of Cronbach's Coefficient Alpha, the data was analyzed by 1) the descriptive equations; 2) structural test models; 3) evaluation of the value of regression (R 2);4) validation of the overall structural model using the Goodness of Fit Index (GoF); 5) Testing the Predictive Relevance (Q 2) LISREL (Linear Structural Relations) program version 8.70. The instruments used were declared valid variables (AVE value $>0.5$ ) and reliable (Cronbach Alpha > 0.90). The results of this study indicate that Green Transformational has a positive and significant effect on corporate sustainability, Green Transformational Leadership has a positive and significant effect on Green Motivation, Green Motivation has a positive and significant effect on Corporate Sustainability, Innovation has a negative and not significant effect on Corporate Sustainability, Innovation has a positive and significant towards Green Motivation, Green Transformational Leadership has a positive and significant effect on Corporate Sustainability through Green Motivation, Innovation has a positive and significant effect on Corporate Sustainability through Green Motivation.
\end{abstract}

Keywords: Corporate Sustainability, Green Transformational Leadership

\section{Introduction}

According to the United State Census, by 2020 , more than $50 \%$ of the world's workforce in 2020 is a millennial generation. The demographic statement is obtained based on the age range of millennial generation. The United State Census explains that there is no official data regarding the range of millennial births, because there are many differences of opinion between countries. However, on average it is said that millennials are those aged 22 to 36 years in 2020, in other words they were born between 1982 and 1998 [1]. The growth of the population of millennial generation born in the world of technology is faster than the previous generation of Baby Boomers and generation $\mathrm{X}$, causing the emergence of a new 
business called the business " startup ". The start-up business in Indonesia, which began in 2010 experienced rapid growth to place the country of Indonesia as the country with the fifth highest start-up company in the world [2]. However, the number of start-up companies in Indonesia which has been counted as many as 992 startups based on BPS data is still relatively low when compared to conventional companies in Indonesia which have reached 26.71 businesses or companies [3].

Start-up companies that have absorbed as many as 55,903 workers have great potential for Indonesia to minimize the problem of unemployment. The majority of start-ups are being recorded (88.25 percent) have a number of employees more than 50 people and only company startup in Indonesia that employs more than 500 people [2]. The main determinant of the sustainability of the start-up business lies in its human resources as the source of the designer of the start-up product which is a software program [4]. The profession of someone who works at a start-up company is also called data scientist.

As with the challenges of company start-ups greater than a conventional company, it takes strategy so that the company remains able to sustain and continue to survive. After research on start-up companies with consumers in the form of individuals is increasingly being raised as an object, researchers look for different companies to become research objects. The company that was made the object this time was a start-up company with consumers in the form of a corporation, namely $\mathrm{T}$ Tri Digital Perkasa. In an interview with Business Director of PT Tri Digital Perkasa, Albert Nicolas, he said that PT Tri Digital Perkasa has been operating since 2015 to design platforms (software) for big data analysis needs in large-scale corporations. The company is able to combine data in CSV, XLS, XLSX, MySQL, Oracle, IBM DB2, Microsoft SQL Server, and other formats easily even in just one click.

The sustainability of the company is not yet stable due to the lack of optimal management of human resources in a company. Sustainability can be realized with the steps that the determination of the company, its vision, mission, goals for innovation quality of human resources in order to increase the amount of absorption through the dimension of human resources .; Mapping of HR needs, soft skills and leadership capabilities, Mapping talent management where there is the role of green motivation, employee engagement through the process of receiving objective and transparent $\mathrm{HR}$ as well as other roles such as government policy and employee productivity levels [ 5 ] .

Based on the first pre-study, PT Tri Digital Perkasa as a start-up company has sustainability factors that are different from conventional companies in general. With the results that are Leadership, Innovation, and green motivation as the most important factor. Talent Management which is one of the sustainability factors that has 7 indicators, namely: green job design and analysis, green recruitment, the shaping of green discipline at work, green development, green performance evaluation, green motivation, and green HRM procedures. Based on pre-research, millennial generation is a generation that requires high motivation. For this reason, researchers are interested in making green motivation one of the variables in this study [7]. Furthermore, this research is expected to provide benefits in terms of explaining the influence of Green Transformational Leadership, Innovation and Green Motivation on Corporate Sustainability at PT Tri Digital Perkasa. 


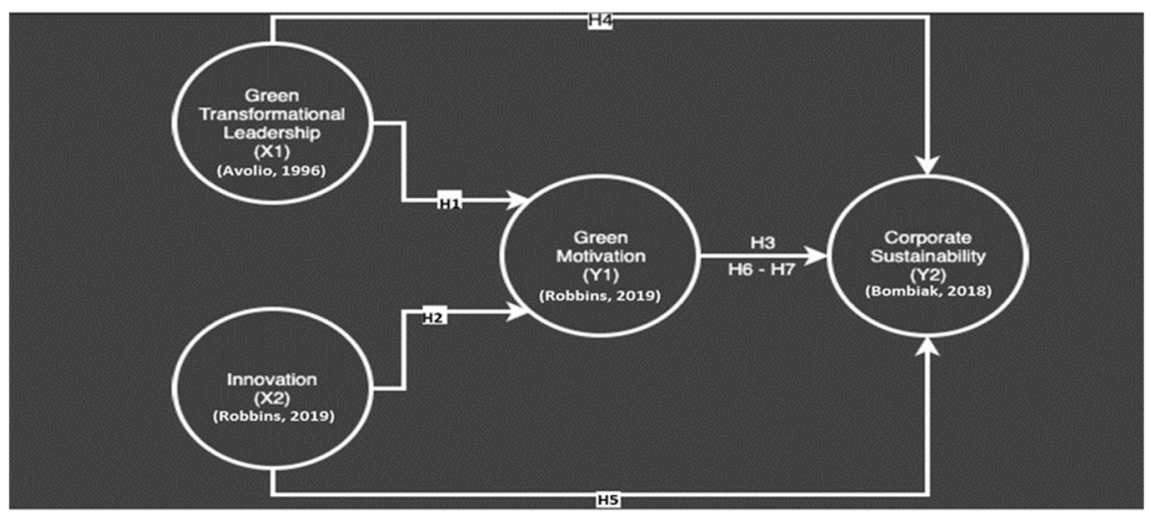

Fig 1. Research Thinking Framework (Source: Researcher, 2019)

Hypothesis : Green Transformational Leadership has a positive and significant effect on the Corporate Sustainability of PT Tri Digital Perkasa.

H2 : Green Transformational Leadership has a positive and significant effect on PT Tri Digital Perkasa's Green Motivation.

H3 : Green Motivation has a positive and significant effect on the Corporate Sustainability of PT Tri Digital Perkasa.

H4 : Innovation has a positive and significant effect on the Corporate Sustainability of PT Tri Digital Perkasa.

H5 : Innovation has a positive and significant effect on the Green Motivation of PT Tri Digital Perkasa.

H6 : Green Transformational Leadership has a positive and significant effect on Corporate Sustainability through PT Tri Digital Perkasa's Green Motivation.

H7

: Innovation has a positive and significant effect on Corporate Sustainability through PT Tri Digital Perkasa's Green Motivation.

\section{Research Method}

This study uses a correlative quantitative research method, which is to see the effect of Green Transformational Leadership and Innovation variables on Corporate Sustainability through Green Motivation at PT.Tri Digital Perkasa. The population of this research is all employees of PT Tri Digital Perkasa. The sample used in this study is the population that truly represents the real conditions so that the research results are truly accurate. The sampling technique used is saturated sampling. So, the number of samples used in this study were all employees of PT Tri Digital Perkasa of 64 employees. Data is collected according to a quantitative approach that is with the study of literature to underlie and strengthen the results and questionnaires.

Instrument research variables Green Transformational Leadership and Innovation to Corporate Sustainability through Green Motivation the form of a questionnaire with Likert scoring models were completed by respondents in the questionnaires that were distributed. Data analysis techniques in this study used Structural Equation Modeling (SEM) with Partial Least Square (PLS). Data analysis uses step 1) descriptive analysis with equation 1;2) test 
the structural model; 3) evaluate the value of regression ( $\mathrm{R} 2$ ) consists of three classifications: R2 value of $0.67,0: 33$ and $0: 19$ as substantial, moderate and weak [11]. Furthermore, cooperation 2; 4) Validate the overall structural model by using the Goodness of Fit Index (GoF) with equation 3; 5 ) Testing Predictive Relevance (Q 2 ) with equation 4 that serves to validate the model.

\section{Results and Discussion}

\subsection{Outer Model Testing}

The outer model can specify the relationship between latent variables and other indicators. Tests conducted on the outer model using the Confirmatory Factor Analysis (CFA) technique. The initial research stage of developing loading factor values of 0.5 to 0.6 is said to be sufficient, and is shown by the Average Variance Extracted (AVE) value above 0.50 .

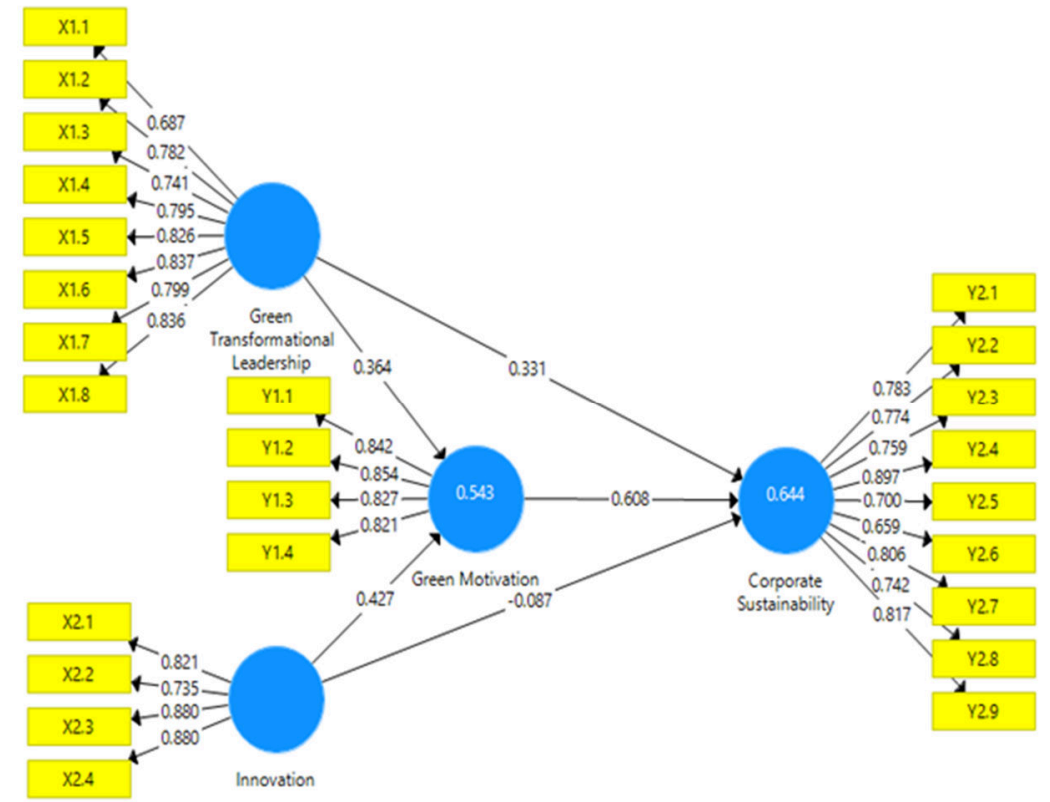

Fig 2. Testing the Outer Model

Furthermore, the discriminant validity is measured through the cross-loading value and the comparison value of AVE and AVE square root. Another test to evaluate the outer model is to look at the construct reliability of latent variables measured by two maca measures, namely composite reliability and Cronbach alpha of the block of indicators that measure the construct. In the first stage, the construct is declared to be reliable if it has a composite reliability value above 0.70 (Imam Ghozali, 2016). Following the output of the outer model of AVE and composite reliability. 
Table 1. AVE (Average Variance Extracted) and Value of Composite Reliability of the Research Model

\begin{tabular}{lc}
\hline & $\begin{array}{c}\text { Nilai Average Variance } \\
\text { Extracted (AVE) }\end{array}$ \\
\hline Green Transformational Leadership & 0.6231 \\
Innovation & 0.6907 \\
Green Motivation & 0.6991 \\
Corporate Sustainability & 0.5983 \\
\hline Sumber : Pengolahan Output Program SmartPLS
\end{tabular}

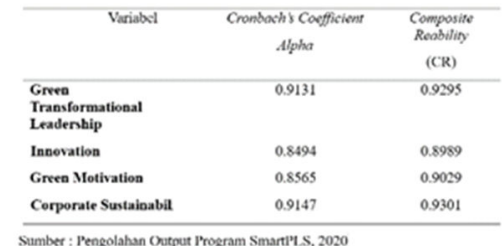

\subsection{Inner Model Testing}

Before testing the hypothesis, the inner model is evaluated first. The Inner Model is analyzed by looking at the significance of the relationship between constructs shown by the coefficient of determination $\left(\mathrm{R}^{2}\right)$, Goodness of Fit Index $(\mathrm{GoF})$, Predictive Relevance $\left(\mathrm{Q}^{2}\right)$, path coefficient and Effect Size $\left(\mathrm{f}^{2}\right)$.

Table 3. $\mathrm{R}$ Square Value $\left(\mathrm{R}^{2}\right)$ of the Research Model

\begin{tabular}{lc}
\hline & $\mathbf{R}^{2}$ \\
\hline Green Motivation & $\mathbf{0 . 5 4 3 5}$ \\
Corporate Sustainability & $\mathbf{0 . 6 4 3 6}$ \\
\hline
\end{tabular}

The Smart PLS output results concluded that the coefficient of determination of this research model can be said to be sufficient on the green motivation variable with an $\mathrm{R} 2$ value of 0.5435 and on the corporate sustainability variable can be said to be good with an R2 value of 0.6436 .

Table 4. Path Coefficient, t-Statistics, and P-Values values

\begin{tabular}{|c|c|c|c|c|c|c|}
\hline \multirow{2}{*}{ Variabel } & \multirow{2}{*}{ Dimensi } & \multicolumn{2}{|c|}{ Green Motivation (Y1) } & \multicolumn{3}{|c|}{ Corporate Sustainability (Y2) } \\
\hline & & $\begin{array}{c}3.1 \\
\text { Insentif }\end{array}$ & \begin{tabular}{|c|}
5.2 \\
Penghargaa
\end{tabular} & $\begin{array}{c}4.1 \\
\text { Ecology }\end{array}$ & $\begin{array}{c}4.2 \\
\text { Economic }\end{array}$ & 4.3 Social \\
\hline \multirow{4}{*}{$\begin{array}{c}\text { Green } \\
\text { Transformationa } \\
\text { l Leadership } \\
\text { (X1) }\end{array}$} & $\begin{array}{l}1.1 \text { Idealized } \\
\text { Influence }\end{array}$ & 0,844 & 0,798 & 0,786 & 0,793 & 0,835 \\
\hline & \begin{tabular}{|l}
1.2 Inspirational \\
Motivation \\
\end{tabular} & 0,833 & 0,813 & 0,793 & 0,799 & 0,828 \\
\hline & \begin{tabular}{|l|} 
1.3 Intellectual \\
Motivation
\end{tabular} & 0,850 & 0,829 & 0,804 & 0,808 & 0,848 \\
\hline & $\begin{array}{l}1.4 \text { Individualized } \\
\text { Consideration }\end{array}$ & 0,829 & 0,804 & 0,786 & 0,785 & 0,822 \\
\hline \multirow{2}{*}{ Imnovation $(\mathrm{X} 2)$} & $\begin{array}{l}2.1 \text { Orgamizational } \\
\text { Innovation }\end{array}$ & 0,847 & 0,813 & 0,790 & 0,814 & 0,843 \\
\hline & $\begin{array}{l}2.2 \text { Green System } \\
\text { Innovation }\end{array}$ & 0,861 & 0,815 & 0,827 & 0,812 & 0,861 \\
\hline \multirow{2}{*}{$\begin{array}{c}\text { Green } \\
\text { Motivation (Y1) }\end{array}$} & 3.1 Insentif & - & - & 0,839 & 0,830 & 0,870 \\
\hline & 3.2 Penghargaan & - & - & 0,809 & 0,817 & 0,840 \\
\hline
\end{tabular}

Source: SmartPLS Analysis, 2019

\subsection{Analysis of the Effect of Green Transformational Leadership on Corporate Sustainability}

The results of this study stated that Green Transformational Leadership had a positive and significant effect on Corporate Sustainability at PT Tri Digital Perkasa. Other studies show that distributed leadership can be a useful basis for instilling sustainability in a company. It functions as a theoretical framework and platform for practical strategies. There are many obstacles to implementing sustainability at a higher level, and distributed leadership is a way to successfully overcome some of these obstacles. Previous studies have highlighted the difficulties of promoting cultural change throughout sustainability-oriented 
organizations. The findings of this study indicate that such cultural change is achieved through good and distributed leadership. can be a useful basis for instilling sustainability in a company. It functions both as a theoretical framework and platform for practical strategies.

There are many obstacles to implementing sustainability at a higher level and distributed leadership is a way to successfully overcome some of these obstacles. Previous studies have highlighted the difficulties of promoting cultural change in all organizations that are oriented towards sustainability [6]. The findings of this study indicate that such cultural change is achieved through good and distributed leadership. Green Transformational Leadership is creative leaders who support environmental sustainability; besides that, they encourage their followers to be creative as well. Companies that have transformational leaders have decentralized responsibilities, greater risks, and compensation plans directed towards long-term outcomes where all company facilities are supported to preserve the environment [7].

\subsection{Analysis of Effect of Green Transformational Leadership Against Green Motivation}

The results of this study stated that Green Transformational Leadership had a positive and significant effect on the Green Motivation of PT Tri Digital Perkasa. This shows that the relationship between Green Transformational Leadership variables and Green Motivation is significant with a value of influence of $36.43 \%$. Leadership has a positive and significant effect on employee performance, meaning that leadership is an effort to influence many people to achieve institutional goals is expected to cause positive changes in the form of dynamic forces that can coordinate institutions in order to achieve goals if implemented in accordance with the corridor established by both parties according with the position owned [8]. Green Transformational Leadership is creative leaders who support environmental sustainability; besides that, they encourage their followers to be creative as well. Companies that have transformational leaders have decentralized responsibilities, greater risks, and compensation plans directed towards long-term outcomes where all company facilities are supported to preserve the environment [7].

\subsection{Analysis of the Effect of Green Motivation on Corporate Sustainability}

The results of this study stated that Green Motivation had a positive and significant effect on the Corporate Sustainability of PT Tri Digital Perkasa. This study is in line with the results of Irwan's research (2016) showing there is a motivational effect on the sustainability of the Phinisi Ship business in Bulukumba Regency, this can be seen from the increased sales of vessels. Motivation for competitiveness in the sustainability of phinisi ship business becomes a benchmark in maintaining quality and competing in marketing phinisi ship sales $[9]$.

\subsection{Influence Analysis of Innovation Against Corporate Sustainability}

The results of this study stated that Innovation had a negative and not significant effect on the Corporate Sustainability of PT Tri Digital Perkasa. Start-up companies have a different character from conventional companies so the results of this hypothesis are negative. Supported by the journal of sustainability factors in internet usage among young people [10], it was explained that not all innovations are able to have an impact on sustainability. According to Hasim, sustainability will occur if company members are satisfied with the impact of the applied innovation, satisfaction from the innovation is also called gratification. However, PT Tri Digital Perkasa's innovations that have not been running optimally will have a negative effect on the company's sustainability. So the results 
of the hypothesis show that H4 is rejected and Ho is accepted. Innovation is a new idea that is applied to initiate or improve a product, process, or service. Innovation is change that refers to making things different. innovation will imply change but not all changes introduce new ideas or lead to significant improvements [11].

\subsection{Innovation Effect Analysis Against Green Motivation}

The results of this study stated that Innovation had a positive and significant effect on the Green Motivation of PT Tri Digital Perkasa. This hypothesis is in line with the results of Situmorang (2013) research on the Effect of Textbook Innovations on Students 'Motivation and Good Character, measurement of students' motivation and learning in chemistry teaching has been done by asking students for opinions on the teaching and learning process experienced by students in two treatment groups. The results show that there is an increase in learning outcomes caused by increased learning motivation of groups of students who get chemistry textbooks resulting from innovation $[12]$. Innovation is a new idea that is applied to initiate or improve a product, process, or service. Innovation is change that refers to making things different. innovation will imply change but not all changes introduce new ideas or lead to significant improvements [1 1 l .

\subsection{Analysis of Effect of Green Transformational Leadership Against Corporate Sustainability Through Green Motivation}

The results of this study stated that Green Transformational Leadership had a positive and significant effect on Corporate Sustainability through the Green Motivation of PT Tri Digital Perkasa. Graves's (2013) findings imply that transformational leadership environment and employee motivation have important effects on company sustainability [1 3 ]. Our results show that an environment with green transformational leadership is very important to facilitate employees' green motivation behavior, whether they are independent or externally motivated or motivated internally. Organizations that want to encourage employees to be involved in corporate sustainability must ensure that leaders have the ability to provide green transformational leadership on issues related to the environment.

Green Transformational Leadership is creative leaders who support environmental sustainability; besides that, they encourage their followers to be creative as well. Companies that have transformational leaders have decentralized responsibilities, greater risks, and compensation plans directed towards long-term outcomes where all company facilities are supported to preserve the environment [7] .

\subsection{Influence Analysis of Innovation Against Corporate Sustainability Through Green Motivation}

The results of this study stated that Innovation had a positive and significant effect on Corporate Sustainability through PT Tri Digital Perkasa's Green Motivation. H Situmorang (2013) research results on the Effect of Textbook Innovations on Students' Motivation and Good Character. The results show that there is an increase in learning outcomes caused by increased learning motivation of groups of students who get chemistry textbooks resulting from innovation [12] . Furthermore, the relationship of motivation influencing sustainability has also been explained by Irwan (2016) which shows there is a motivational effect on the sustainability of the Phinisi Ship business in Bulukumba Regency, this can be seen from the increased sales of vessels [9]. Innovation is a new idea that is applied to initiate or improve a product, process, or service. Innovation is change that refers to making things 
different. innovation will imply change but not all changes introduce new ideas or lead to significant improvements [11].

\section{Conclusion}

Based on the results of the analysis concluded that Green Transformational Leadership has a positive and significant effect on Corporate Sustainability, Green Transformational Leadership has a positive and significant effect on Green Motivation, Green Motivation has a positive and significant effect on Corporate Sustainability, Innovation has a negative and insignificant effect on Corporate Sustainability, Innovation has an effect on positive and significant impact on green motivation, Green Transformational has a positive and significant effect on corporate, Innovation has a positive and significant effect on Corporate Sustainability through Green Motivation. Of the seven calculations and analysis states that six calculations and analysis states that there is a positive and significant influence one calculation and analysis states a negative and not significant effect.

\section{References}

[1] Vespa, Jonathan. (2017). The Changing Economics and Demographics of Young Adulthood: 1975-2016. United States Cencus Bureau US Departement of commerce Economic and Statistic Administration (cencus.gov).

[2] Kominfo. (2019). Jumlah Startup di Indonesia Ratusan atau Ribuan?. [Online]. Tersedia: https://kominfo.go.id/content/detail/17233/jumlah-startup-di-indonesia-ratusan-atauribuan/0/sorotan_media. (Diakses Juli 2020).

[3] BPS, 2018).

[4] Simamora, B. (2013). Memenangkan Pasar Dengan Pemasaran Efektif dan Profitabel. Jakarta: PT Gramedia Pustaka Utama.

[5] Lenny dan Farida. (2017). Framework Sustainability Strategi Sumberdaya Manusia. Seminar Nasional Inovasi dan Aplikasi Teknologi di Industri 2017. Institut Teknologi Nasional Malang: 4 Februari 2017

[6] Wright dan Horst. (2013). Exploring the ambiguity: what faculty leaders really think of sustainability in higher education. International Journal of Sustainability in Higher Education, Vol 14 (2), pp. 209-225.

[7] Bombiak, Edyta. (2018). Green Human Resource Management as a Tool for the Sustainable Development of Enterprises: Polish Young Company Experience. Journal of Siedlce University, Vol 10 (6), pp. 2-22.

[8] Irwan, Khusnul Khatimah, Muhlis R dan Arifudin M. (2016).Pengaruh mtivasi terhadap keberlanjuatan usaha kapal phinis di Kabupaten Bulukumba. . Journal Unibos Makasar vol 3 no.002.

[9] Situmorang, Manihar. (2019). Pengembangan Buku Ajar Kimia SMA Melalui Inovasi Pembelajaran dan Integrasi Pendidikan Karakter untuk meningkatkan Hasil belajar Siswa. Prosiding Semirata FMIPA Universitas Lampung 